

\section{El Retrato Pictórico devocional como reflejo de la etnicidad y la sociedad hispánica en Centroamérica}

Juan Haroldo Antonio Rodas Estrada

Historiador por la Universidad de San Carlos de Guatemala. Maestro en Historia del Arte por la UNAM, culminando su doctorado. Docente de San Carlos y Francisco Marroquín de Guatemala. Dirigió el Centro de Estudios Folklóricos, el área de investigaciones de la Escuela de Historia, integró el Consejo Superior de Investigaciones, la Dirección General de Investigaciones y el Museo de la Universidad de San Carlos, todos de Guatemala. Dirige el Museo Fray Francisco Vázquez. Miembro de los comités de evaluación para el Aporte de Descentralización Cultural de su país natal. Ha coordinado varios proyectos de investigación en su país y el extranjero. Es autor de ocho libros y varias publicaciones especializadas en revistas y enfoques periodísticos.

6 . Avenida 4-67 zona 2. Guatemala, ciudad.

Telf.

22381678 - fax 22500508

Correo

Electrónico jhrodas@intelnet.net.gt

Unidad de

Historia del Arte Departamento de Educación

Universidad Francisco Marroquín 


\section{Introducción}

Este título engloba historia del arte y cultura, plantea un diálogo en la expresión material como reflejo de la sociedad de la Capitanía General de Guatemala, inscrito en un sentido donde la especialidad no es precisamente delimitada, ya que conlleva como el hombre mismo una interacción en la que se aprecian ideas, expresión artística, cotidianeidad y el espíritu que mueve al hombre.

La pintura muestra un momento preciso de la sociedad que la creó. Pose múltiples aspectos que determinan si es o no una pieza de orden significativo, reflejo del sentimiento, la expresión, la visión social y étnica de la sociedad que la generó. Muestra la devoción como parte del ritual que se desarrolló para entonces, visualizando las diferencias étnicas, socioeconómicas y la compleja conformación de una sociedad en la que convivieron espíritu, identidad y razón de españoles, indígenas, negros, mestizos y criollos, tejiendo leyendas, mitos y tradiciones que enlazaron a los grupos de ayer, y pueden ser hoy puntos básicos para iniciar el reencuentro.

Se trata de presentar el arte como producto de la creación humana, resultado de un proceso que el individuo generó como parte de un sostén para su propia estructura y estabilidad, liberandose y trazando un sueño, que al igual que en la literatura deja libertad para el alma y el pensamiento. Contemplemos parte de estos resultados, en los que se resumen las ideas de orden prehispánico y cristiano, generando un modelo único, sencillo, práctico, pero ante todo generador de satisfacciones que se dan cuando el hombre logra un diálogo entre su yo interno, y de quienes lo rodean.

\section{Concepto y variaciones del Retrato}

Existen varias formas para contemplar una imagen, pero sea cual fuere se da una respuesta que cuestiona si es el hombre el que ha creado ese símbolo o es el símbolo el que modela al hombre, quizás porque el concepto divino y espiritual es generado por el propio hombre, pero este nace, crece y se manifiesta a través del mismo y por lo tanto está inmerso culturalmente dentro de un sentir. 
Con estas premisas se desarrolla también una apreciación en torno al poder que ofrecen las imágenes que a través de ritos y mitos se convierten en símbolos tras los que podemos fijar una posición mística, pero también un orden de idolatría o la representación de una realidad con la que el hombre fija su conciencia y se eleva hacia Dios, fijando posiciones dentro de la tierra, haciéndolas vivas, quizás contemplándolas desde un orden votivo, o como elementos consagrados, tras cuyos ritos se eternizan entre los hombres, porque cobran vida y se transforman en seres que son algo más que humanos.

Esta visión es factible gracias a las apreciaciones de teóricos y especialistas que por diversas razones no han incluido referencias de la América Hispánica, donde las obras adquieren una ideosincrasia muy particular, adaptadas a un proceso de mestizaje entre español, indígena y negro, pero con regionalismos donde es posible establecer mecanismos que el hombre ha generado para hacer una divinidad local dentro de un universo de creencias y dimensiones espirituales.

Las apreciaciones de Nicos Hadjinicolaou ${ }^{1}$ y de David Freedberg ${ }^{2}$ en cuanto a la falta de análisis de piezas latinoamericanas, justifica este interés en quienes intentamos hacer una historia del arte y de la simbología en el medio. Marca un reto para incorporar estos ejemplos a una teoría de apreciación de símbolos y deidades ya establecidas en cuanto a origen y desarrollo.

El problema de la América hispánica, es más complejo, hay arte, divinización y satanización de la misma, una dualidad de creencias sobre un mismo símbolo. Aquí está el hombre mismo representado, no sólo de espíritu y conciencia, sino que de composición étnica, linaje y posición social. En cada simbolismo hay un poco de todo: se es hombre con variadas raíces: étnicas y mentales, pero al final, todos de una u otra forma crean un modelo tras el que se encuentran con Dios y se reencuentran permanentemente, a lo largo de los siglos consigo mismos, para hacer emerger en esas creencias la propia libertad.

Se concibe como imagen o "efigie," a una imitación figurativa, pudiendo ser del original, o bien concentrarse en el vestuario o elementos que identifican a quien es representado. Puede $1 \quad$ Nicos Hadjinicolaou. Historia del Arte y lucha de clases. (México, Editorial Siglo XXI, 1974), pp. 3-4 2 David Freedberg. El Poder de las Imágenes. (España, Ediciones Cátedra, 1992), pp. 11-17 
ser de un modelo natural, tal como las máscaras funerarias de las culturas antiguas, o bien como atuendo para exaltar a un personaje, como sucedió con los mayas al distinguir su posición social quedando en un segundo plano el aspecto físico.

Su función más importante es recordar a un individuo, ya fuese física o bien por sus obras trascendentales. Exalta la personalidad, se clasifica en un género muy particular y busca la exhibición del poder y privilegios.

Sus tópicos son: literario, histórico, artístico y devocional. En primer orden por la narración oral y escrita donde son descritos los valores de alguien o de algo. Lo histórico se concentra en la búsqueda de los valores pasados, presentando dos modalidades: el histórico y el conmemorativo.

El criterio artístico, reproduce el modelo original, tal como sucede con los retratos de la Virgen de Guadalupe, que se dicen tocados al original, reafirmando que son una copia fiel. Finalmente está el devocional influido por lo histórico y artístico, identifica una imagen para exaltarla y venerarla, pudiendo o no ser un modelo totalmente original, o bien idealizado, pero mostrándolo como algo sobrenatural o espiritual.

El retrato se muestra así con objetos simbólicos, su postura, el vestuario y su entorno. Genera un mensaje psicológico de poder e impacto, se acrecenta por su tamaño, formato, dimensión, estilo, y desde luego por el uso de materiales y técnicas, ya que a través de ello se expresará la vitalidad, nobleza y elegancia. No voy a ampliar más este aspecto, ya que existen tratadistas al respecto, y en Guatemala se cuenta con el enfoque producido por Carlos Morán. ${ }^{3}$

Las imágenes son retratos idealizados de los santos, transformándoles de sus verdaderas características a seres divinos adaptando un nuevo criterio corporal que los transforma de mestizos a blancos, comparándoseles a los apóstoles y santos bíblicos que se constituyen en parámetros de valores estéticos para los demás que surgen en la historia, particularmente a los latinoamericanos que van desde un orden étnico, mestizo, a la pureza de sangre, que asoma con 3 Carlos Mauricio Morán Alvizúrez. El retrato al óleo durante la época colonial; evolución simbólica: del barroco al neoclásico. Tesis de grado (Guatemala, sin editorial, 1999) 
la blancura de piel, como sucede con Santa Rosa de Lima o bien el propio Hermano Pedro, un español pobre y lastimado que ahora asoma en los altares con un rostro de español con linaje. ${ }^{4}$

La sociedad del período hispánico encontró modelos a seguir en conducta y valores, forma y expresión. El problema no fue como cohesionar una sociedad a través de ello, sino en encontrar un punto de partida a través de Cristo. Los retratos tomaron modelos históricos o narrativos, supuestamente escogidos por Dios, como sucede con el rostro de la escultura del Nazareno del templo de la Merced de Guatemala considerado por una monja como el más parecido al rostro natural de Jesús, ya que ella en un sueño recibió este mensaje y lo expandió para hacer valer esta escultura como lo más sublime y parecido a la faz de Jesús. ${ }^{5}$

\section{El Nazareno y su trascendencia social y cultural en Guatemala}

La existencia del Nazareno Mercedario de Guatemala sobrepasa así el orden material, pero antes de adentrarnos en el estudio de sus retratos, debemos tomar en cuenta que la representación del Nazareno tiene en Guatemala una trascendencia que nos obliga a contemplar el concepto y su impacto social. El Nazareno -según la Real Academia Española- es la representación de la "Imagen de Cristo con vestido de talar de color morado, que tira a rojo y el pelo tendido" ${ }^{6} \mathrm{Se}$ enfatiza en esos colores pero en Guatemala se le ha dotado de variadas túnicas color melón, celeste y otros más, obedeciendo a un sentido cultural. Destaca por el uso de pelo tendido, traducido como pelo suelto, aunque acá por ser cabellera de pelo natural se le peina con canelones.

La representación de Jesús con la cruz a cuestas, derivó del Concilio de Trento (1545 1563), proliferó, fue difundido por las acepciones estéticas de Hans Holvein, un alemán que representó por primera vez a Jesucristo con la cruz a cuestas. En España destacaron Pedro Berruguete (1440-1504/1490-1561.?), Juan de Juni (1507-1577), Gregorio Fernández (15764 Anónimo. La capilla de Santa Rosa de Lima. Altar de la Patria (Lima, Servicio Gráfico Editorial, S.A.) y Ricardo Toledo Palomo. Retratos del Santo Hermano Pedro. (Guatemala, Caudal S. A., 2002)

$5 \quad$ Miguel Álvarez Arévalo. De Ramos a Pascua. (Guatemala, Fondo Editorial la Luz. Serviprensa Centroamericana, 1992) Breves consideraciones sobre la historia de Jesús de la Merced. (Guatemala, Serviprensa Centroamericana, 1980) y Gerardo Ramírez Samayoa. Consagrada Imagen de Jesús Nazareno del templo de Nuestra Señora de las Mercedes. (Guatemala, s.p.i. 2,000 )

6 Diccionario de la Lengua Española. Academia Española Madrid, España, 1970. p. 911. El subrayado es mío. 
1630), además de los escultores sevillanos, a los cuales están ligados los primeros artistas del período hispánico del nuevo mundo.

No podemos asegurar con exactitud, cuál fue la primera manifestación plástica en que se representó a Cristo cargando la cruz en la Capitanía General de Guatemala, pero suponemos que la misma fue conocida por medio de los grabados, ya que en España los Nazarenos cargan la cruz en el lado derecho, mientras que en Guatemala lo hacen en casi su totalidad en el lado izquierdo, dejando el lado derecho visible con un giro del rostro.

La primera talla de un Nazareno de la cual se tenga la noticia en Guatemala está asentada en el libro de cofradía del Nazareno del templo de la Merced de Guatemala, donde desde "1582 hasta 1654, que entraron por mayordomos, Juan Manuel Vásquez Montiel y Nicolás Pérez de Santa María, tuvo la cofradía en su capilla una imagen de Jesús Nazareno que era de los Padres,"”lo cual permite reafirmar que en 1582 existía una talla de un Nazareno, se desconocen sus dimensiones y descripción.

Fue hasta 1655, en que el escultor Mateo de Zuñiga dotó al templo Mercedario de un Nazareno, iniciándose la producción de esta representación en Guatemala. Todos los que le siguieron en el orden de aparición cronológica, partieron de este modelo estético, lo cual varia en muy raras excepciones. El Nazareno mercedario carga la cruz en el hombro izquierdo, vuelve su mirada al derecho, se inclina en este sentido y tiene además un giro helicoidal, a la manera de la columna salomónica que culmina con un paso, en el que los pies quedan uno adelante y otro atrás del cuerpo.

Así surgió un patrón artístico, repitiéndose en los siglos XVII y XVIII, definiendo los Nazarenos de Guatemala, agregándole cabelleras, ya que eliminó el pelo tallado, y la forma de revestirlo con túnica y un cíngulo o cinturón largo.

El Nazareno Mercedario adoptó un patrón español, pero confeccionado con manos criollas, tanto su escultor, el maestro Mateo de Zúñiga, como su pintor Joseph de la Cerda son criollos,

$\overline{7} 2$ Álvarez. 
trabajaron para una cofradía del mismo grupo, transformándose como un patrón a seguir por otros grupos que encontrarán en él una motivación para fijar en sus imágenes sus características étnicas.

\section{Trascendencia del Nazareno en la sociedad guatemalteca}

La imagen del Nazareno asumió un papel en la historia y el presente en Guatemala, colocando así el sentido del ser social que el arte cumple en el medio, y contemplar en esencia el impacto que tuvo en la vida cotidiana de sus habitantes.

En el siglo XVI,--según Erick Golf, ${ }^{8}$ - a la llegada del español, la población de Mesoamérica contaba 24 millones, pero a fines de ese siglo se redujo a menos de tres. La gente se hostigó, y cayó en el terror, sin encontrar consuelo, su cultura casi desapareció. Las devociones españolas enfatizaban en lo Mariano, pero esta situación varió en América y particularmente en Guatemala, dónde la veneración de las imágenes de pasión se centró en gran parte en Jesús, como el elemento principal de los acontecimientos. Fue el Nazareno, el que conquistó mayores devotos. Su existencia fue casi nula en el siglo XVI, únicamente figuró el de los padres Mercedarios. Al otro que algunos autores le han tratado de dar esta antigüedad es el Nazareno de Candelaria, pero esta posición ha sido desechada. ${ }^{9}$

La talla de Jesús Nazareno de la Merced es la primera en su estilo y haciendo eco en las apreciaciones de Prahl, ${ }^{10}$ es el inicio de una configuración de la silueta de los Nazarenos guatemaltecos. Desde entonces la presencia del Nazareno se acrecentó en la segunda mitad del siglo XVII, especialmente entre 1670 a 1700, ya que a través de su presencia se enseñó el sufrimiento y el sojuzgamiento para ganar el paraíso perdido por la desobediencia a Dios, y reconquistarlo con sacrificios.

8 Erick Wolf. Pueblos y Culturas de Mesoamérica. (México, Biblioteca Era. 10a. edición, 1986).

9 Existen varios autores que estudian este tema, pero la mejor apreciación es la de Josefina Alonso de Rodríguez. La Imagen de Jesús Nazareno de Candelaria y la Ermita de Nuestra Señora de los Dolores del Cerro. Inédito.

10 Federico A. Prahl R. "Consideraciones sobre la imagen de Jesús Nazareno de la Merced de Guatemala” en Tradiciones de Guatemala. No. 44. (Guatemala, Fotograbado Llerena S. A., 1995), 95-104 
El Nazareno mercedario representa una huella criolla, fue imitado por otros grupos entonces étnicos incorporados a barrios específicos, como sucedió con los indígenas del Barrio de Candelaria quienes mandaron a tallar en el siglo XVIII su imagen de Nazareno con baja estatura y posición de cargar la cruz en forma diferente, porque mira hacia abajo, como sucede con el indígena que carga el mecapal, aunque su iconografía está posiblemente ligado a un grabado europeo.

La otra variante es el Nazareno alto, fornido, con características negroides, hoy venerado en el templo de la Merced de Antigua procedente del Barrio de los Jerónimos dedicado a los Negros, reflejando así la necesidad de incorporar a cada étnia un elemento que los identifique y a la vez los unifique a una veneración que coincidía con el sacrificio y entrega hacia Dios.

Esto se fortaleció en los primeros años del siglo XIX. El régimen conservador tocó a su fin en 1871, a raíz del triunfo liberal los sectores medios emergentes buscaron un ascenso en la escala social, pero no cambiaron los patrones culturales y sociales del grupo al que estaban arraigados, revitalizaron sus nexos, con el propósito de reproducir los cánones sociales y políticos que habían heredado de la colonia, especialmente la devoción a los Nazarenos, que ya para entonces ocupaban un lugar en la identidad de los guatemaltecos. Estos adoptaron también una postura mestiza, ladina, como sucede con el Nazareno del Calvario, antes perteneciente a los terceros franciscanos. ${ }^{11}$

El siglo XIX culminó con la presencia en el poder de uno de los representantes de estos grupos emergentes, el coronel y licenciado Manuel Estrada Cabrera, un liberal de presencia, pero un conservador de corazón, haciendo surgir él por un sentido personal y por otra parte reflejando lo que los de sus grupos deseaban, una defensa sin igual a los sentimientos de religiosidad popular prevaleciente en las grandes mayorías.

El implantó nuevas costumbres que destacan su religiosidad popular al exigir que las hermandades llevasen sus procesiones hasta su residencia de la Palma, en la actual zona 5 de la ciudad de Guatemala. Además otorgó algunos títulos de patronazgo de Nazarenos para el 11 J. Haroldo Rodas, Encuentro y Reencuentro con el Nazareno del Calvario (Guatemala, Caudal,S. A., 2000) 
Ejército o diversos cuerpos del Estado. Puso en juego una relación entre Religiosidad Popular y Estado, a pesar de tratarse de un gobierno liberal.

Para entonces se inició en Guatemala una transformación de los cultos externos de fe, especialmente de las procesiones de Semana Santa, que circulaban en andas de 4 o 6 brazos, y se les agregó algunos adornos, como el caso del cojín con un resorte que portó por primera vez el anda de Jesús de la Merced, y que fue una novedad creativa para entonces. ${ }^{12}$

En los años 40 y 50 las exaltaciones tomaron auge, lo cual se afianzó en la década del 1944-54. A partir de la década de los 50 tomó auge en la ciudad y Antigua Guatemala, relacionando el culto al Nazareno en los adornos de sus procesiones con hechos de la vida cotidiana contemporánea, como el impacto de muertos, heridos y luchas políticas. ${ }^{13}$

El simbolismo del Nazareno surgió acá en el período hispánico, se proyectó a los siglos subsiguientes para consolidarse en un proceso, en el que el hombre se siente identificado con el mismo, ya que a través de ésta imagen llena de dolor y flagelo ve reflejado su proceso de lucha por obtener la nueva libertad, mostrando un mensaje de unidad y enfrentamiento, en el que el Nazareno es colocado como un bastión de un nuevo proceso de lucha del pueblo guatemalteco.

\section{Los retratos pintados del Nazareno mercedario}

Con esta dinámica social, que va de la colonia hasta la actualidad, surgen pinturas de los Nazarenos, particularmente del Mercedario, convirtiéndose primero en un mensaje casi divino, por lo que todas las personas, y las iglesias mismas deseaban conservar un retrato pintado de aquella efigie que se convirtió en un emblema religioso y cultural, con el cual se identificaron todas las etnias.

Estos retratos asumieron una función similar al de una fotografía. Captaron el instante en que el Nazareno fue velado en el interior del templo hacia finales del siglo XVIII o inicios del XIX. Quizás no existen otros más antiguos, ya que la práctica del retrato de imágenes es una

12 Gonzalo Mejía Ruiz, “Apuntes sobre el altarero guatemalteco”, Tradiciones de Guatemala (Guatemala) 19-30, n. 5 (1977) en la que se incluye una referencia mencionada por el altarero Ramiro Araujo.

13 Haroldo Rodas Estrada, Crónicas de Semana Santa (Guatemala, Caudal, S. A., 2001) 
tendencia de la época referida, porque a ese mismo período corresponden otras reproducciones pintadas de imágenes talladas de gran devoción en Guatemala, como sucede con la Virgen del Rosario, Nuestra Señora de la Merced, el Cristo de Esquipulas, Nuestra Señora del Socorro y la Virgen del Carmen

Existen variados ejemplos pictóricos que reproducen estos modelos tallados, algunos incluso en áreas más lejanas de la ciudad de Santiago, que hoy corresponden a otras regiones mesoamericanas, como Chiapas, México y Honduras. Todos los retratos presentan a la imagen central revestida de trajes casi en su totalidad dorados, demostrando el influjo de la pintura cuzqueña en el medio, lo cual despertó un interés muy particular en la región estudiada.

Este tipo de pintura es muy típico en esta etapa en Guatemala, posee influjo de México y Perú. Con ella se expande la devoción a determinadas imágenes, o bien reafirma cada una de estas veneraciones al nivel familiar en distintos hogares, a la manera de entronizar éstas en cada una de las casas, como se observa actualmente utilizando fotografías de las tallas de gran veneración.

Los lienzos con Jesús Nazareno de la Merced son muy variados. Van desde los domésticos de 20 a 30 centímetros de alto hasta los de más de un metro. Corresponden a un mismo lapso, (Fines siglo XVIII - inicios XIX) factibles de fechar por sus detalles dorados, la composición de la alfombra de flores sobre la mesa en que aparece colocada la escultura de Jesús, que siempre es tricolor: azules, rojas y blancas, en una composición un tanto popular, pero basada en el influjo de la escuela de Flandes, muy evidente en la pintura Guatemalteca a partir de la mitad del siglo XVIII. Las flores son rosas, azulinas y claveles.

Se les puede agrupar por el uso de las túnicas, ya que en la mayor parte se le representa con una de fondo corinto y detalles de hojas doradas, representando el brocado de una de las túnicas antiguas que posee la talla de Jesús. Otro de los bloques corresponde a un traje morado lila con flores diminutas, mientras que en otras dos, la de Mixco y Suyapa, Honduras la imagen está representada con una cruz leñosa y vestimenta lisa color marrón. 
Los dos grupos restantes, uno se integra por el tamaño y calidad de las obras, ambas de más de un metro cincuenta centímetros de alto, con túnicas que simulan brocados con grandes rocallas y finalmente dos pinturas más, una conservada en la ciudad de Guatemala y otra en Chiapas que muestran la talla de Jesús revestido con trajes con cierta similitud con fondos obscuros y hojas resaltadas con dorados y flores.

Destaca por su originalidad un retrato rectangular de 45 centímetros por 70 centímetros de alto, conservado en una residencia guatemalteca donde la imagen posee un traje dorado que simula un brocado con diseños de rocallas, con un fondo de un dosel que cubre de barras doradas y rojas que rompe con el criterio de todas las citadas anteriormente, donde la imagen de Jesús es enmarcada entre cortinajes o bien colocada sobre la mesa.

En todos los cuadros el retrato de Jesús Nazareno está enmarcado con un cortinaje. El figura de pié sobre una mesa con un mantel blanco, sobre el cual, en algunos casos, figuran dos o un florero con flores azules, rojas y blancas, y en otros las mismas flores sobre el mantel. Esto hace suponer que se trata de una velación en la que fue exaltada esta imagen, posiblemente se trate del escenario con que fue conmemorado el centenario de su consagración hacia 1817, o bien el primer altar que fue erigido en honor a Jesús Nazareno con motivo del estreno del templo mercedario hacia 1813.

Es en estas representaciones se da un diálogo entre pintura y grabado. Los retratos pintados del Nazareno Mercedario surgen de un patrón otorgado por un grabado fuente de inspiración para las pinturas, debió reproducirse para promocionar la imagen del Señor de la Merced entre mayor número de fieles, ya que fue otorgado como testimonio de las indulgencias concedidas a quienes rezaran delante de la imagen tallada.

El papel impreso fue llevado a las casas, y llegaron hasta nuestros días muy pocos ejemplos, entre estos uno reproducido en el libro Imágenes de Oro. ${ }^{14}$ Puede atribuirse a Juan José Rosales, el maestro pintor y grabador que tuvo gran trascendencia para ese momento. La línea y calidad del grabado responden a las obras realizadas por Rosales para esa época, presenta el trazo bien $14 \quad$ Miguel Álvarez y Luis Luján Muñoz. Imágenes de Oro. Galería Guatemala. Primera Edición Corporación G \& T. (Guatemala, Litorama, 1993), 16. 
definido y finura en la impresión sobre el papel, resultado de las delicadas incisiones en las planchas metálicas sobre las cuales se ejecutó el diseño original para reproducirlo en papel. ${ }^{15}$

Los medios de reproducción fueron así para procurar un material sencillo y de fácil manejo, aunque no necesariamente se trata de piezas que pudiesen ser conservadas a muy largo plazo, ya que se trata de papel, que por muy resistente que fuese, estaba sometido a factores ambientales y de trato humano, lo cual ocasionó que llegasen muy pocos ejemplares hasta nuestros días. Curiosamente solo una pieza de grabado se conservó en su estado original, en la cual la imagen de Jesús asoma con su túnica brocada y su clásica posición,.

En esta obra se puede observar la posición inclinada de la imagen retratada, así como la colocación de los pies, uno adelante y otro atrás, pero también es factible detectar el cíngulo que se proyecta hasta la mesa donde está colocado y se desliza un poco más del largo de la túnica. Además se detecta la túnica de fondo corinto y estofas doradas que aún se conserva y que aparece en otra foto de esta relación, la cual posiblemente derive de esta misma fecha, lo que es aventurado afirmar porque nunca he podido contemplarla de cerca y establecer si se trata de una tela de esa época o bien corresponde a un período anterior. Sin embargo por el diseño y el brocado se puede tratar de una tela francesa de fines del siglo XVIII.

Podríamos referir muchos aspectos más del grabado, pero desviaría la atención de los retratos pintados y el deseo es únicamente demostrar cómo el grabado que reprodujo un retrato de Jesús de la Merced inspiró a los artistas a crear pinturas inspiradas en este modelo o lo que es más aún a pintar estos grabados. Contemplemos ahora el escenario creativo de los pintores relacionados a este grabado.

Inspirados en ese patrón ha sido posible detectar dos piezas: una pintada sobre tabla y otro en hojalata. Los otros dos son grabados pintados, si bien con alta calidad, demuestran cómo al grabado original se les aplicó color para darles originalidad y naturalidad.

Los ejemplos de grabados pintados están en colecciones particulares. En el primero se dejó

15 Roberto Cabrera. El Grabado Guatemalteco. (Guatemala, Dirección General de Cultura y Bellas Artes. Departamento de Artes Plásticas. s.p.i., 1973) y Edna Núnez de Rodas. Grabados de Guatemala. (Guatemala, Talleres Litográficos del Instituto Geográfico Nacional, 1970) 
exactamente igual, solamente se hizo variar la mesa que fue dotada de flores con tres colores. Al igual que la pieza original grabada, esta pintura representa una velación de la talla de Jesús de la Merced. Destaca la aplicación de pintura en todo el conjunto, Jesús muestra las cruces de consagración en las manos y pies, un detalle que al momento en que fue elaborado y pintado únicamente lo poseía la imagen del Nazareno Mercedario, que fue la primera talla de Nazareno consagrada en Guatemala en 1717.

La túnica de fondo corinto, tiene detalles dorados que forman las estofas simulando el brocado de la original. Esta procede de fines del siglo XVIII y la imagen la lució en alguna ocasión especial del periodo y aún se conserva. Es fácil de detectarla ya que es única en su género y muy antigua. La utiliza hasta la actualidad.

La cruz, es verde, con la vid enredada a la manera de una columna salomónica. Este mismo modelo tal como se conserva en la actualidad muestra un fondo verde, sobre el cual descansa la vid entorchada sobre los brazos de la cruz. En la pintura, la cruz es rematada por cuatro cantoneras, de las cuales se proyectan cuatro puntas o vértices que la cruz ya no posee, por lo que bien puede considerarse una ilusión artística que el autor pudo incorporar para dar un remate visual a la cruz pintada o bien estas piezas existieron y fueron anuladas.

Sin embargo la cruz original de la talla de Jesús de la Merced no fue ésta, ya que los documentos señalan que al momento de ponerse a pública veneración fue con una cruz de madera y no de plata. Esta se mandó inicialmente a guarnecer de plata en marzo de $1742^{16} \mathrm{y}$ posiblemente fue hasta después que se hizo el soporte tubular de plata. Esta apreciación podrá darse hasta que la cruz pueda ser historiada y visualizada.

Además se observa el resplandor sin piedra preciosa, muy similar al que el Nazareno mercedario utiliza en la procesión de la Reseña, o bien al mismo del viernes santo, pero obviamente sin la piedra roja del centro.

La pintura es un retrato del Nazareno Mercedario, basándose desde luego en un concepto 16 Gerardo Ramírez. Consagrada Imagen de Jesús Nazareno del Templo de Nuestra Señora de las Mercedes. (Guatemala, s.p.i., 2002), 32 
estético que asomó desde el siglo XVIII en los grabados anónimos conservados hoy en las colecciones de Museos y particulares que guardan las patentes de cofrades de aquella época, las cuales eran ilustradas con gráficas grabadas por artistas de ese período, dejando así una muestra de ese arte, pero más que ello una huella de cómo visualizaron el perfil y la faz de este Nazareno.

La imagen grabada del Nazareno adoptó una posición. Su perfil, la colocación de la cruz y otros detalles más como lo quebrado del cuerpo por el peso de la cruz, la colocación de las manos sobre la cruz y la posición de los pies uno hacia adelante, asentado en el suelo, y otro hacia atrás levantado en posición en vértice. Es a partir de entonces que la forma de representar al Nazareno Mercedario, se adoptó en todas las efigies que se crearon de Nazarenos en Guatemala, con excepción del Nazareno de Candelaria, que refleja un modelo indígena matizado de características españolas.

En el segundo caso se observan cortinajes, cíngulos, mesas y floreros. En este ejemplo el cortinaje es azul, pende de la parte alta, se abre en dos, a los lados del Nazareno, lo muestra en una escena con cíngulos que penden también de lo alto y recogen las cortinas hacia los lados, dejando una huella que imperará en casi todos los retratos. Esto se percibe también en las pinturas Jesús Nazareno de los templos de la Merced y San Francisco.

En todas las escenas de velación, la imagen del Nazareno se presenta sobre una mesa de altar revestida con un mantel, en algunos casos con encajes que penden del costado, y sobre la mesa varias flores esparcidas, demostrando un tributo, como si fuese una alfombra natural. En el caso del cuadro que centraliza nuestra atención en este momento hay además un encaje que pende hacia abajo y una inscripción que alude a Jesús de la Merced, confirmando que dicha imagen es un retrato de la talla del Mercedario, colocándolo como un retrato artístico, tocado al original.

En los cuadros figuran también floreros con rosas, claveles y choreques, todas de colores azul, rojo, y blanco, en el caso del primero hay dos floreros con pájaros, en otros solo aparece un florero, y en el caso de la pintura del Nazareno de Mixco estos se sustituyen por dos candeleros y dos velas prendidas. 
Estas composiciones son inspiradas en un mismo modelo que surgió de la velación de un Lunes Santo del Nazareno Mercedario en la ciudad de Guatemala, lo cual sirvió de inspiración a los artistas posteriores que fijaron un concepto estético que no es repetitivo, ya que se alimenta de otros elementos, pero deja una huella perecedera, quizás porque la pintura, que también cumplió, en el período colonial, una función similar a la que hoy corresponde a la fotografía, nos dejó una huella imborrable de los grandes acontecimientos al interior de los templos durante la época cuaresmal, pero reflejando en ello el sentimiento y el valor que la gente daba a la escultura del Nazareno Mercedario, considerado como algo divino, pero otorgándole variaciones en las que desde luego es posible descubrir un sentimiento étnico, ya que en algunos cuadros Jesús pasa de ser un criollo, a alguien de otras características.

\section{El cuadro convertido en ovalo}

El segundo ejemplo de grabado pintado es un óvalo, originalmente un grabado rectangular adherido a una tabla. Es el mismo impreso utilizado para la pintura descrita inicialmente, solamente que en este caso el grabado fue adherido a una tabla ovalada y se le agregó pintura para ampliar el espacio de fondo de la imagen, el cual es oscuro y no presenta cortinaje.

El fondo tiene dos tonos, uno mas oscuro que el otro, ya que el papel se adhirió a la madera pero destaca con una tonalidad más clara, mientras que la madera absorbió mas el negro. Abajo la mesa sobre la cual está la imagen, se presenta vacía, solo con un mantel blanco y sin mayores detalles de calado, sin embargo con el paso del tiempo ha asomado en la parte inferior una lectura con rasgos similares al grabado.

La imagen de Jesús muestra cruz más larga, ya que se amplió por la forma ovalada y se proyecta hacia arriba en mejor forma que otros porque no tiene limitación de cortinaje. Varia en cuanto a la túnica, aunque se trata de la misma descrita en el ejemplo inicial. Es de fondo verde con detalles de estofas pero colocadas en forma de arcos y ondulaciones que dan otra visión, pero siempre basado en la posición del grabado. El cíngulo es de un solo cordón que llega a los pies y se dobla hacia delante. 
Este cuadro difiere del anterior no sólo por su forma sino que además conserva el marco original con detalles dorados y una moña neoclásica hacia arriba, lo cual afianza el período de las pinturas descritas, correspondientes a inicios del siglo XIX.

\section{La túnica verde}

Al primer grupo de pinturas se une otra pintada al óleo sobre madera, donde Jesús tiene túnica verde igual que la cruz, solamente que el tipo de estofa se arquea como el segundo caso descrito. No incluye cortinajes ni siquiera mesa. Aunque se basa en el grabado anterior no es un grabado pintado, incluye detalles dorados tanto en las estofas del brocado de la túnica como en la cruz.

Destaca su rostro con detalles de sangre, enmarcado entre un resplandor de rayos dorados a manera de un abanico parejo, creando una suntuosidad en la cabeza y destacando el rostro que es por cierto uno de los mejor conservados.

\section{La obra sobre hojalata}

Se agrega a este segmento de retratos un óleo sobre hojalata en el que Jesús está enmarcado en el cortinaje pero esta vez de color rojo, presenta todos los detalles descritos anteriormente, varia por el color de la túnica que es rojo suave con estofas doradas simulando la túnica de brocado francés ya referida.

La cruz es de fondo verde y vuelve a presentar la guarnición de piezas de plata formando una vid entorchada en los brazos.

La imagen de Jesús figura colocado sobre una mesa recubierta de mantel sin flores esparcidasSuma dos floreros dorados con flores azules, rojas y blancas. El mantel que cubre la mesa se proyecta hacia abajo y al final un letrero que dice Jesús de la Merced.

Lamentablemente esta obra debido al material que tiene de soporte, está desprendiendo el 
color, pero aún es factible detener su deterioro para conservar este ejemplo pictórico. El soporte ayuda también a identificarla como una obra popular.

De este grupo, con excepción de la segunda, todas las pinturas son rectangulares, miden entre 25 y 30 centímetros de alto, mientras que el ovalo alcanza 31 centímetros.

\section{El Nazareno Dorado}

Hay otra versión de un Nazareno en la misma posición que los descritos, pero en este caso no incluye cortinaje y únicamente resalta la imagen con una túnica totalmente dorada, como que fuese un estofe, más que una pintura plana, ya que los dorados tienen ligeros relieves. La cruz es similar a lo referido, con la vid, pero también es dorada, casi podríamos referirla como un dorado sobre dorado, ya que el resplandor y todos los detalles que lo complementan también son dorados.

Es conservada en una casa particular de Honduras, afianzando el criterio que fueron las imágenes las que dieron unidad a la región, tratando de contemporizarlas entre familias de poder y linaje, demostrando así signos de unidad entre los grupos de una provincia y otra durante el período hispánico.

Esta pintura cobra un vigor muy significativo por el enmarcado que posee, ya que el mismo tiene incrustaciones de concha nácar y hueso, ejemplificando el taraceado que surgió en la región, demostrando la vitalidad que enlaza lo hispánico, lo indígena, expresado en el gusto del dorado y los elementos mudéjares, creando un verdadero ejemplo de mestizaje que no cuenta sólo con los elementos españoles y prehispánicos, sino que se proyecta a algo mucho más rico y abundante.

\section{El grupo de la túnica morada}

El segundo grupo de retratos está integrado por dos obras realizadas al óleo, una sobre madera y otra en hojalata. En ambas la imagen figura con una túnica morado lila con 
aplicaciones de flores, simulando los bordados de flores en hilos dorados que debió poseer la original. Lamento no conocer el inventario de túnicas del Nazareno Mercedario, porque facilitaría establecer esta vestimenta y su fechamiento.

En ambos retratos la postura es más hierática, pero destaca la cruz con la vid y la posición de los pies en la misma forma que en los anteriores, agregándose naturalmente las cruces de consagración y finalmente los detalles de flores sobre el mantel donde descansa la imagen.

Ambas pinturas tienen 30 centímetros de alto y una pincelada un poco más libre, pero no por ello faltas de gracia y detalle.

La primera está sobre tabla, presenta un fondo celeste y la imagen de Jesús con túnica morada y cíngulo que cae más debajo de la túnica, colocado sobre la mesa con flores dispersas de tonos rojos y azules. La cruz verde es igual a las descritas.

En el caso de la pintura sobre hojalata la posición también es hierática, pero se observa una leve inclinación. La túnica morada con detalles de flores doradas, pero esta vez con cortinaje que enmarca la imagen y abajo la típica mesa con mantel blanco y flores azules y rojas destacadas por lo resaltado del blanco. Esta pintura conserva muy bien los colores originales ya que tiene recubrimiento de vidrio.

Ambas pinturas proceden del siglo XIX y son posteriores a las descritas.

\section{El retrato del dosel}

Esta es la pintura más original, la imagen de Jesús pintada en óleo sobre tela muestra en el fondo un dosel con fondo rojo y galones dorados en forma vertical. Sorprende el dosel por la presencia de un brocado simulado que se deja entrever al fondo del rojo, ya que son detalles que el pintor logró con efectos, como que fuese una serigrafía y se pierden desde lo lejos al contemplar la pintura. 
Posee cruz verde con la vid, se torna dorada con cantoneras. El cuello tiene un leve giro que hace volver la mirada de Jesús hacia el frente, coronado de espinas y un resplandor redondo que simula plata sobredorada o mestiza.

La túnica es blanca con rocallas doradas, una posición que lo hermana en cierta forma a los retratos grandes que serán descritos posteriormente. Pareciese simular un estofe, como si se tratase de representar una pieza tallada y estofada y no a una de vestir como es el caso del Nazareno Mercedario. El cíngulo simula ser de hilo dorado y se perfila hacia el frente debajo de la túnica. Esta última presenta los mismos pliegues que el grabado y las primeras cuatro pinturas aludidas al inicio.

Las manos y pies incluyen las cruces de consagración, pero curiosamente sobre la muñeca de la mano derecha carga una llave, posiblemente la de su propio camarín, o bien como la iglesia que él protege, aunque puede tratarse de las llaves de la ciudad de Guatemala que el ayuntamiento le confirió nombrándolo protector jurado de la misma.

\section{Los retratos de Mixco}

A los grupos anteriores se agregan dos cuadros más: uno existente en Mixco, Guatemala y el otro en Suyapa, Honduras. He referido estos cuadros como los retratos de Mixco, porque por tradición se sabe que el cuadro existente en la casa de la Cultura de Mixco fue pintado cuando la imagen de Jesús pasó por este lugar en su traslado de la Antigua a la Nueva Guatemala. hacia 1776.

Tradición o leyenda, deja asentada una evidencia del motivo del retrato y al ser el de Suyapa muy similar, ambos fueron catalogados como pinturas de Mixco, porque supuestamente evocan este grato acontecimiento a fines del siglo XVIII, aunque pudiese identificárseles como del Traslado.

En ambos Jesús está revestido con túnica marrón oscuro, el cíngulo es un lazo y no un cordón dorado como en los anteriores, el cual cae debajo de la túnica, expandiéndose sobre la mesa, mientras que no aparece con resplandor redondo, sino con otro en forma semicircular, 
tipo abanico, con sus tres potencias, colocado en forma ilusoria ya que no sigue la posición de la cabeza, sino una forma ideal para que el devoto aprecie su rostro.

La efigie central está dispuesta siempre en un enmarcado de cortinas que pueden ser parte de un palio que lucía antes en su antigua anda. En el caso de la pintura procedente de Mixco el cortinaje es oscuro y en el otro rojo, pero en ambos tienen galones dorados en las orillas. En este caso la cruz es leñosa con detalles dorados que resaltan el interior de la madera.

La mesa es lisa cubierta del mantel blanco que cae en ondulaciones leves como un mantel de altar, el cual está recubierto de rosas rosadas y únicamente incluye como tributos dos candeleros con velas muy altas.

El cortinaje del de Suyapa es rojo, el fondo oscuro y la túnica marrón oscuro pero con galones dorados en el cuello mangas y final de la túnica. La cruz solo presenta dorados en dos esquinas. Jesús está sobre una mesa con dos jarrones con flores blancas, rojas y azules. Difiere del anterior por el cíngulo de lazo adornado con rosas rojas.

Ambos cuadros posiblemente proceden de un mismo pintor, autodidacta, libre, cuya creatividad dejó una evidencia muy subjetiva de la presencia de Jesús en una velación o quizás de algún acontecimiento en especial. Esto nos reafirma una teoría que hasta ahora se está probando, la existencia de obras gemelas, que no fueron copias, sino ambas originales producidas por un mismo artista, pero destinadas a recintos diferentes.

En ambos cuadros hay interés de presentar a la imagen de Jesús con un sentido distinto al que posee, pero el giro, la colocación de los pies y la inclinación hacen ver que se trata de la misma representación de un mismo Nazareno y aunque lamentablemente no tienen una anotación ni firma, puede ser obras del mismo autor, ligados a la influencia del período en que la pintura con detalles dorados se hizo evidente en la Capitanía de Guatemala. Tienen dos metros de alto y 1.30 de ancho y fueron ejecutados en óleo sobre tela y se encuentran en buen estado de conservación. 


\section{El hermanamiento de Chiapas y Guatemala}

Existe en el templo de San Francisco de San Cristóbal las Casas, Chiapas, México, una pintura que vuelve a evocar la presencia del Nazareno Mercedario reconocido como La Caída de Cristo. Aquí está representado en un enmarcado similar a los anteriores, con su cortinaje, pero al frente hay una cenefa que une las cortinas, reafirmando la idea que se trata de un palio que cubría su antigua anda. Para algunos críticos chiapanecos esta composición no tiene explicación y señalan la presencia del cortinaje como algo descontextualizado en una escena de la pasión, ${ }^{17}$ lo cual es comprensible si no está enlazado a la serie de retratos que ahora se integra en este documento.

La figura central con su cruz verde, con vid de detalles plateados y cantoneras, similares al original. El resplandor y el movimiento del rostro, así como las partes visibles del cuerpo, manos y pies con cruces de consagración deja lugar a pensar que se trata de dicha imagen.

La túnica es obscura, con fondos grisáceos, encima posee hojas doradas y flores rojas, recordando diseños de brocados del siglo XVIII. Las orillas de la túnica, tanto en el cuello como en las mangas y el final de la túnica presentan galones dorados que pretenden resaltar el ropaje con esplendor. El cíngulo dorado se prolonga hasta debajo de la túnica y se dobla hacia el frente.

La imagen está colocada en una mesa con mantel blanco, acompañado de rosas rojas, no posee ninguna inscripción, pero se trata de la imagen de Jesús por la posición, la cruz y ante todo las cruces de consagración en las manos y pies.

Resulta extraño contemplar hoy en día que exista un cuadro semejante, el cual es de mas de un metro de alto, en la región chiapaneca, pero hay que recordar que esta área de Mesoamérica perteneció a la Capitanía de Guatemala y sin duda hay una relación de cultos y desarrollo artístico entre ambos espacios, tal como sucede con la propia catedral de San Cristóbal basada en los patrones de fachada de la Catedral de Santiago de Guatemala, hoy la Antigua Guatemala.

17 Paula Mues Orts. “Cruce de Caminos: el arte de pintar y esculpir en Chiapas, siglo XVI al XIX” en Arte Virreinal y del siglo XIX en Chiapas. (México, Pinacoteca 2,000), 62 y 64 
Esto hace pensar en una comunicación permanente en ambas regiones, como sucedió con el ejemplo anterior ubicado en Suyapa, Honduras, pero en este caso no solo existen retratos del Nazareno Mercedario, los hay también de la Virgen del Rosario, El Socorro y el Cristo de Esquipulas que fueron pintados en lienzos y llevado a distintas iglesias de San Cristóbal, reafirmando así una unidad de creencias y devociones populares.

\section{El Nazareno del Altiplano}

Se reconoce así a la imagen de Jesús que figura en un camino quebradizo del Altiplano Occidental de Guatemala, una versión muy singular, ya que pareciese que Jesús camina en un gólgota con paisaje chapín, algo así como los nacimientos donde Jesús nace en el paisaje natural guatemalteco. La obra mide 1.40 de alto por $1 \mathrm{~m}$. De ancho.

Está representado con túnica corinta, casi café con detalles de girasoles dorados con hojas. Se relaciona un tanto con el de Chiapas por los detalles dorados de las túnicas, pero difiere en la composición de fondo, ya que el anterior es con cortinajes y en éste Jesús figura un camino pedregoso con ligeros follajes y un cielo con celajes propios del altiplano.

Curiosamente las manos y los pies no incluyen las cruces de consagración, pero la posición de los pies y el movimiento de la túnica dejan entrever la influencia del grabado a que se hizo alusión al inicio.

Ambas son pinturas proceden de fines del siglo XVIII y aunque ya no reproducen los mismos esquemas que observan las obras clasificadas en el primer grupo, especialmente en la segunda, da lugar a una composición más creativa y talvez atrevida en su momento, pero se trata de obras más formales, de composiciones que sin duda dicen mucho de la calidad que alcanzó la pintura guatemalteca en esa época.

\section{Los retratos mayores}

Asoman finalmente el grupo de los cuadros que reproducen la imagen del Nazareno 
Mercedario en mayores dimensiones, superan el metro sesenta y cinco centímetros y tienen un metro de ancho. El primero pertenece a la iglesia de la Merced puesto a pública veneración. Presenta a Jesús en su clásica composición centrado entre cortinajes rojos, con fondo oscuro, resaltando con una túnica blanca con detalles de brocado dorado ocre.

La imagen siempre dispuesta sobre una mesa sencilla cubierta con un mantel blanco, porta la cruz verde con detalles de la vid plateados y cantoneras que simulan plata, con cantonera acompañadas de piedras preciosas.

La talla de Jesús tiene un giro hacia la derecha y muestra la posición de las manos y los pies en la misma forma que es visible en los anteriores, pero curiosamente ninguna de sus extremidades tiene las cruces de consagración, pero se le define como retrato del Nazareno Mercedario, primero porque está dentro del recinto eclesiástico que le pertenece y segundo por su giro y posición para cargar la cruz, además de los detalles de la misma que son sin duda alguna los que siempre caracterizaron al Nazareno aludido.

Además se complementa con el mismo movimiento característico en la imagen de Jesús de la Merced y luego figura el cíngulo como que fuese de plata, largo que pende desde el cuello en dos hilos que caen hasta debajo de la túnica doblándose en sentido contrario a todos los cuadros, ya que figura en orden hacia la izquierda.

La mesa en que está colocado está recubierta con un mantel blanco y en esta forma pareciese que se trata de una andarilla, de la cual penden ondulaciones con cierto resaltados o bordados en blanco. Encima de éste dos floreros simulando ser de oro y plata y llenos de rosas rojas, lo cual confirma la composición clásica en los retratos pintados de Jesús de la Merced.

\section{El retrato del templo Franciscano}

Para concluir uno de los cuadros con proporción y calidad. Se trata de la representación del Nazareno Mercedario con un movimiento que le hizo variar la posición del rostro, lo cual pareciese que no se trata de él, sino de Jesús de Candelaria, ya que mira hacia abajo. Aunque 
pudiese contemplarse dentro de esa perspectiva, al ser enmarcado en las posiciones anteriores, con cortinajes similares en un posible palio y luego sobre una mesa cubierta de mantel blanco, con flores y agregar un florero confirma que se trata de un retrato del Nazareno Mercedario.

La cruz es similar a todas las anteriores, tiene una vid enredada en los travesaños y presenta las cantoneras típicas que caracterizan la cruz que porta el Nazareno Mercedario. La túnica es un tanto similar a la del retrato que permanece en el templo de la Merced, fondo claro con rocallas ocres con galones dorados en el cuello, las mangas y el final de la túnica.

Las manos y los pies no tienen las cruces de consagración, pero el logro de los detalles de estas extremidades ofrece más detalle que en todos los casos anteriores.

El mantel blanco sirve de fondo a las flores de colores azul, rojo y blanco, que aparecen desparramadas en el mantel y otras colocadas en floreros. Todas son parte del influjo que la escuela de Flandes hizo en la pintura guatemalteca, pero demuestran como los artistas criollos pudieron formular soluciones propias en las que demostraron creatividad utilizando los característicos azules y rojos provenientes del añil y la cochinilla o posiblemente el achiote. ${ }^{18}$

En este caso la composición de las flores, el florero, la calidad de ejecución de las extremidades y el detalle que asoma en el tornillo de sostén de la cruz y la imagen, una flor confeccionada de plata sobredorada hacen que este cuadro se convierta en la mayor ilusión de la forma de captar a la imagen de Jesús de la Merced, demostrando como hubo un desarrollo que al final llevó a realizar obras de alto sentido creativo como ésta.

La obra es la máxima expresión del retrato del Nazareno mercedario que unido a los anteriores forman una referencia de cómo los distintos pintores respondiendo a una necesidad de distintos sectores sociales de su época retrataron la vida y el alma de una etapa de la historia de Guatemala a través de la talla que puede considerarse más simbólica y emblemática, quizás porque supo captar el espíritu de los hombres de su época, pero mas que ello, pudo con su fuerza trasladarse hacia los grandes momentos de la historia subsecuente del país, enmarcándose en el momento de

18 Haroldo Rodas Estrada. Pintura y Escultura Hispánica en Guatemala. (Guatemala, Caudal, S. A. 2002) 
la pasión, ese sentimiento que hermana a los guatemaltecos de ayer y hoy.

Sea como fuere los artistas de ese período retrataron una imagen tallada que se convirtió en un emblema, un símbolo de mestizaje. Fue el retrato con el que los criollos idealizaron a Jesús, matizaron a un hombre que sufre, sustituyéndolo por el modelo español, para convertirlo a través de ello en el gran pendón tras el que empezó a erigirse la libertad, primero creativa y después ideológica.

Atrás vinieron otros artistas, los que con su punzón grabaron la silueta de esa imagen y los que la pintaron, transformándola, idealizándola, pero siempre llevando con ello un mensaje que impulsaba a nuevos derroteros. Quizás por ello, al surgir la talla del Nazareno Mercedario marcó el deseo de todos los grupos étnicos de la época de contar con algo similar, y luego con el avance del tiempo, el discurrir de múltiples embates, motivó a que los pintores retrataran aquella emblemática imagen para convertirla en un símbolo de esperanza que debía permanecer en otras iglesias del Reyno de Guatemala, pero también en los hogares, porque al final, él había conquistado corazones, marcando una nueva ruta de esperanza para los hombres de Guatemala, que hoy como ayer, guardan el deseo de conservar sus valores para emerger desde ello con autenticidad y lucha.

El retrato del Nazareno Mercedario demuestra asíla permanencia de esta escultura entre la sociedad guatemalteca, pero que no incluye únicamente a los habitantes de la provincia del mismo nombre, sino a todas las que conformaron la Capitanía General de Guatemala, ya que la figura además de Chiapas y Suyapa se hizo presente en la capital de Honduras, donde aún permanece un retrato dorado con un marco de conchanacar, lo cual demuestra el interés de la población de esta región de hermanarse a un grupo de poder con linaje, brindándole a esta representación un lugar preferencial que los uniese a los habitantes de la capital de la Capitanía, ya que así se reproducían múltiples aspectos de poder.

El Nazareno mercedario se convierte así en un elemento que surgió en el período colonial, convirtiéndose en un péndulo cultural que viaja de ayer a la actualidad para consolidar su posición como un emblema de poder y unidad para la población. Sin embargo, esta no fue la única versión de retratos que asomó en la Capitanía de Guatemala, ya que junto a ello se pueden contemplar 


\section{ay) concaso \\ 9 5 CENTRDAMERICANO \\ LL IIISIOKIA}

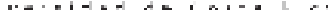

Indexaciones: Repositorio de Revistas UCR, DIALNET, Latindex, REDALYC Directorio y recolector de recursos digitales del Ministerio de Cultura de España, Directory of Open Access Journals.

Diálogos Revista Electrónica de Historia ISSN 1409- 469X. Número especial 2008. Dirección web: http://historia.fcs.ucr.ac.cr/dialogos.htm

las reproducciones de otras representaciones de Jesús, como sucede con el Cristo de Esquipulas, los Niños Dioses y desde luego varias advocaciones Marianas que tuvieron gran veneración en la capital de esta región, especialmente la Virgen del Rosario del templo de Santo Domingo que se tornó en el símbolo de poder y gloria de esa orden y la provincia de Guatemala, brindado una señal de unidad y reverencia de las castas.

Anexos

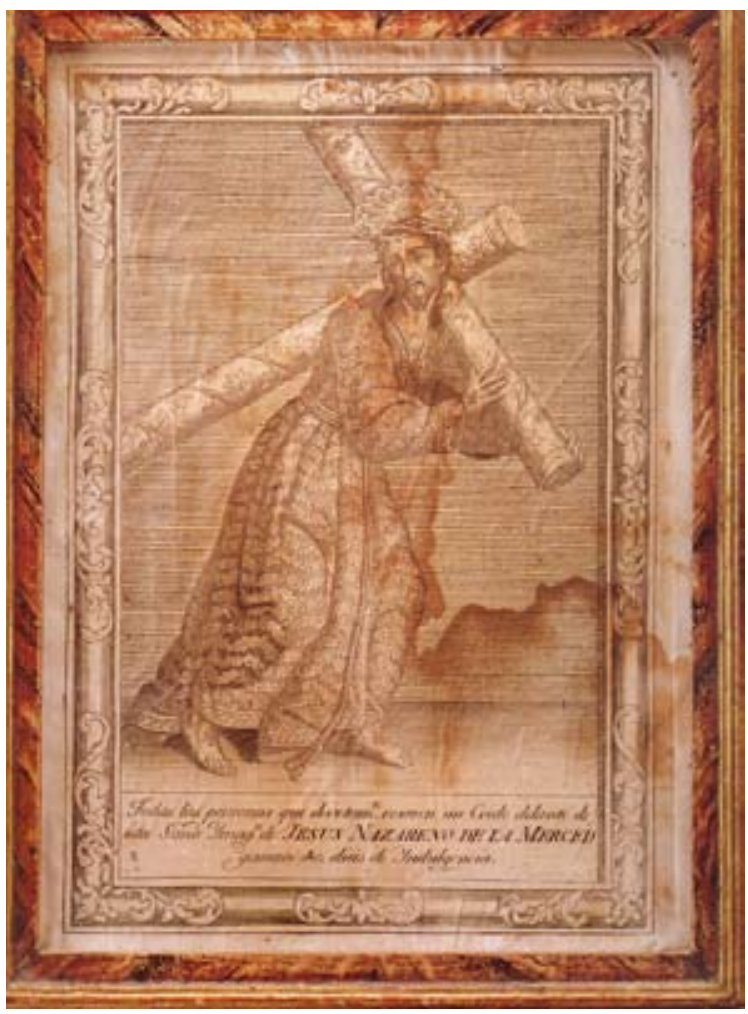

Grabado de Jesús de la Merced editado a inicios del siglo XIX, posible obra de Juan José Rosales, pintor y grabador guatemalteco. 


\section{ON9 $9^{\circ}$ CONGRESO \\ 9 $\$$ CENTROAMERICANO \\ of UL IIISIOIA}

- - +

Indexaciones: Repositorio de Revistas UCR, DIALNET, Latindex, REDALYC Directorio y recolector de recursos digitales del Ministerio de Cultura de España, Directory of Open Access Journals.

Diálogos Revista Electrónica de Historia ISSN 1409-469X. Número especial 2008. Dirección web: http://historia.fcs.ucr.ac.cr/dialogos.htm

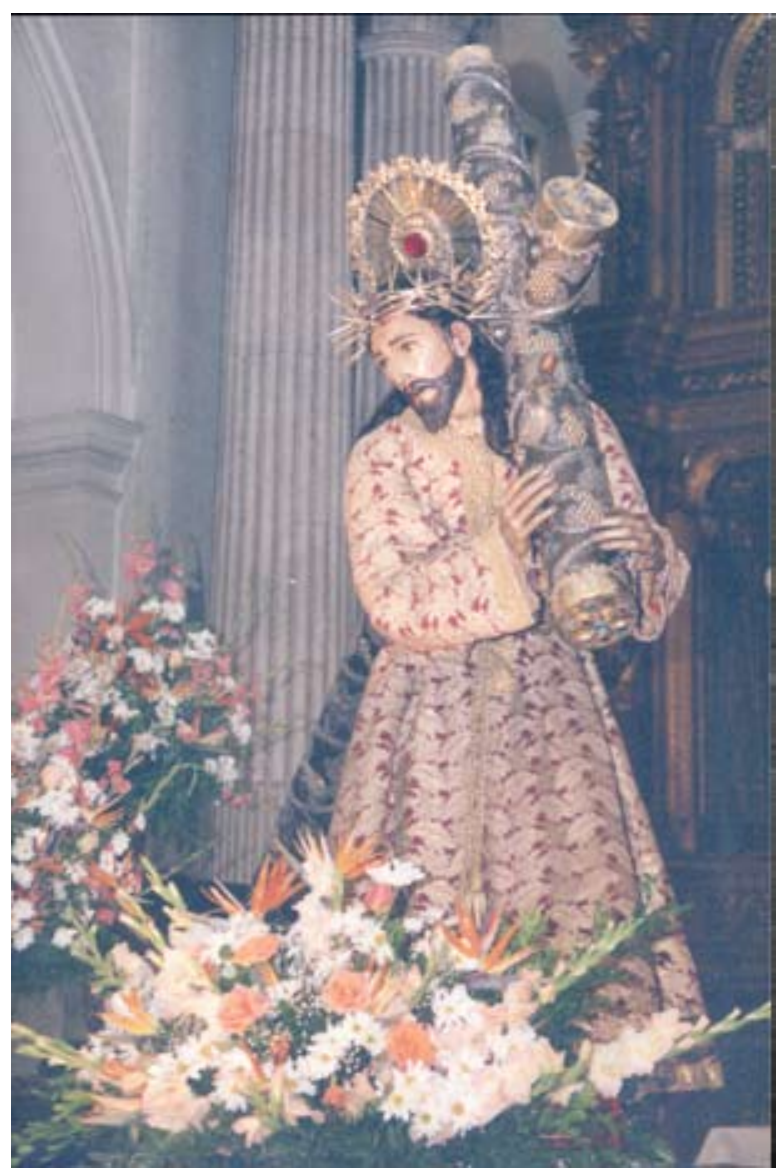

Foto de la escultura de Jesús Nazareno de la Merced revestido con la túnica de fondo corinto y hojas brocadas doradas 


\section{9) $99^{\circ}$ CONGRESO \\ D) CENTROAMERKCANO \\ of $\mathrm{C}$ UL IIISIOIA}

Indexaciones: Repositorio de Revistas UCR, DIALNET, Latindex, REDALYC Directorio y recolector de recursos digitales del Ministerio de Cultura de España, Directory of Open Access Journals.

Diálogos Revista Electrónica de Historia ISSN 1409- 469X. Número especial 2008. Dirección web: http://historia.fcs.ucr.ac.cr/dialogos.htm

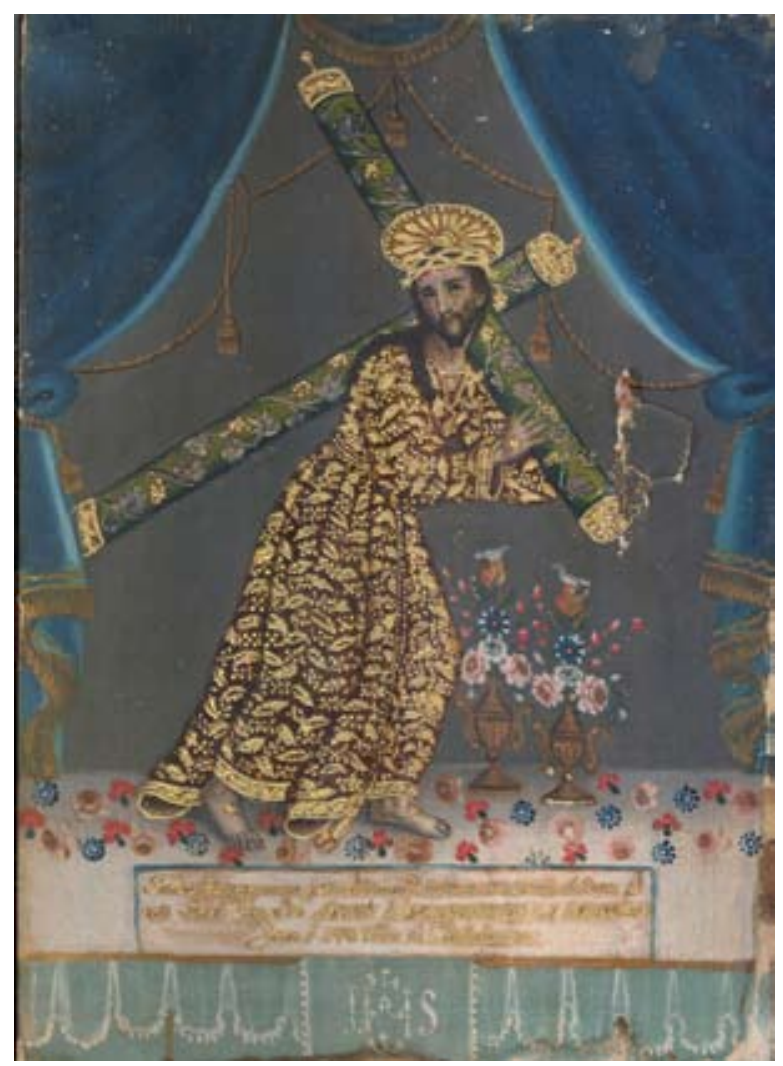

Grabado pintado con la efigie de Jesús de la Merced. Note la similitud de la túnica y los detalles de la cruz, unido a los elementos que tipifican una velación 


\section{9) $99^{\circ}$ CONGRESO \\ g) CENTROAMERICANO \\ LL IIISIORIA}

Indexaciones: Repositorio de Revistas UCR, DIALNET, Latindex, REDALYC Directorio y recolector de recursos digitales del Ministerio de Cultura de España, Directory of Open Access Journals.

Diálogos Revista Electrónica de Historia ISSN 1409-469X. Número especial 2008. Dirección web: http://historia.fcs.ucr.ac.cr/dialogos.htm

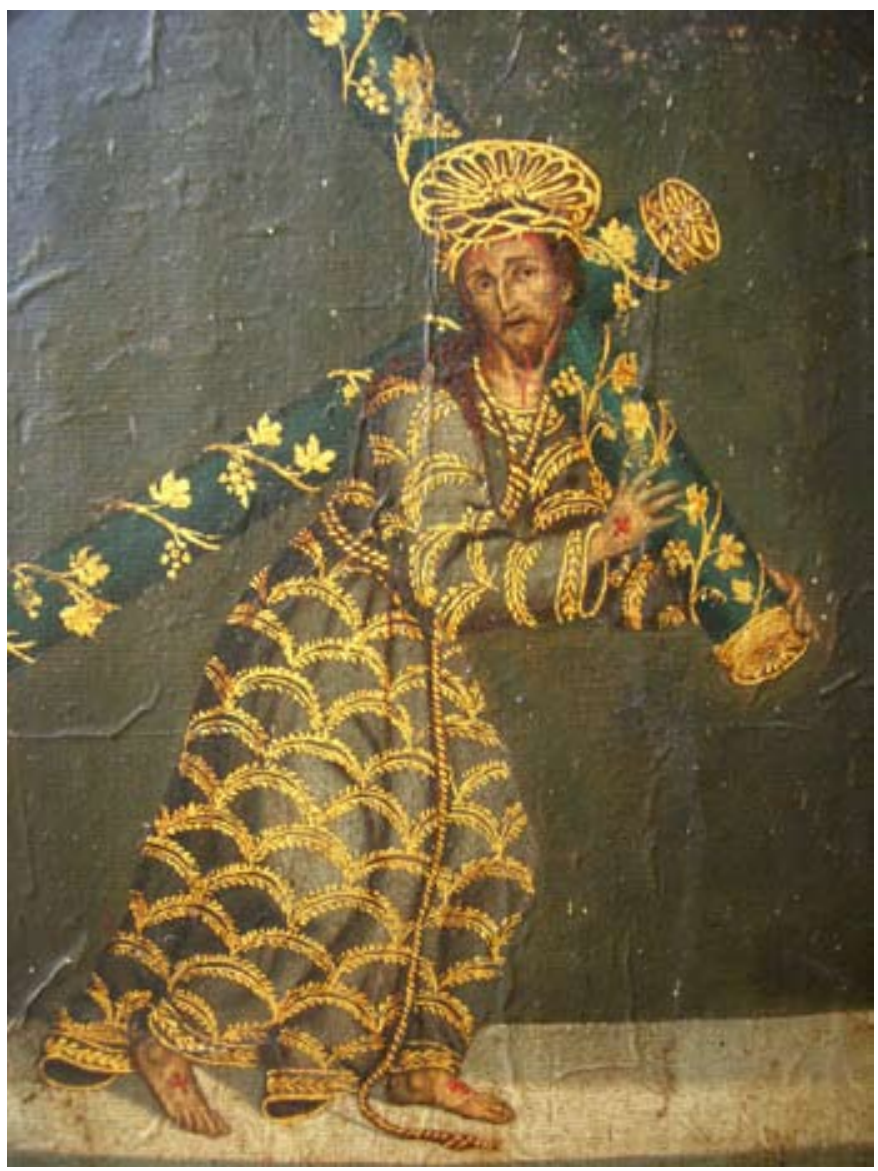

Otro de los grabados pintados, pero en este caso la túnica se torna verde oscuro con los relieves dorados de las ramazones estilizada que recuerdan la tela original 


\section{9 $99^{\circ}$ CONGRESO \\ 9) CENTROAMERICANO \\ of $\mathrm{C}$ UL IIISIOIA

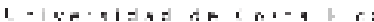

Indexaciones: Repositorio de Revistas UCR, DIALNET, Latindex, REDALYC Directorio y recolector de recursos digitales del Ministerio de Cultura de España, Directory of Open Access Journals. Diálogos Revista Electrónica de Historia ISSN 1409-469X. Número especial 2008. Dirección web: http://historia.fcs.ucr.ac.cr/dialogos.htm

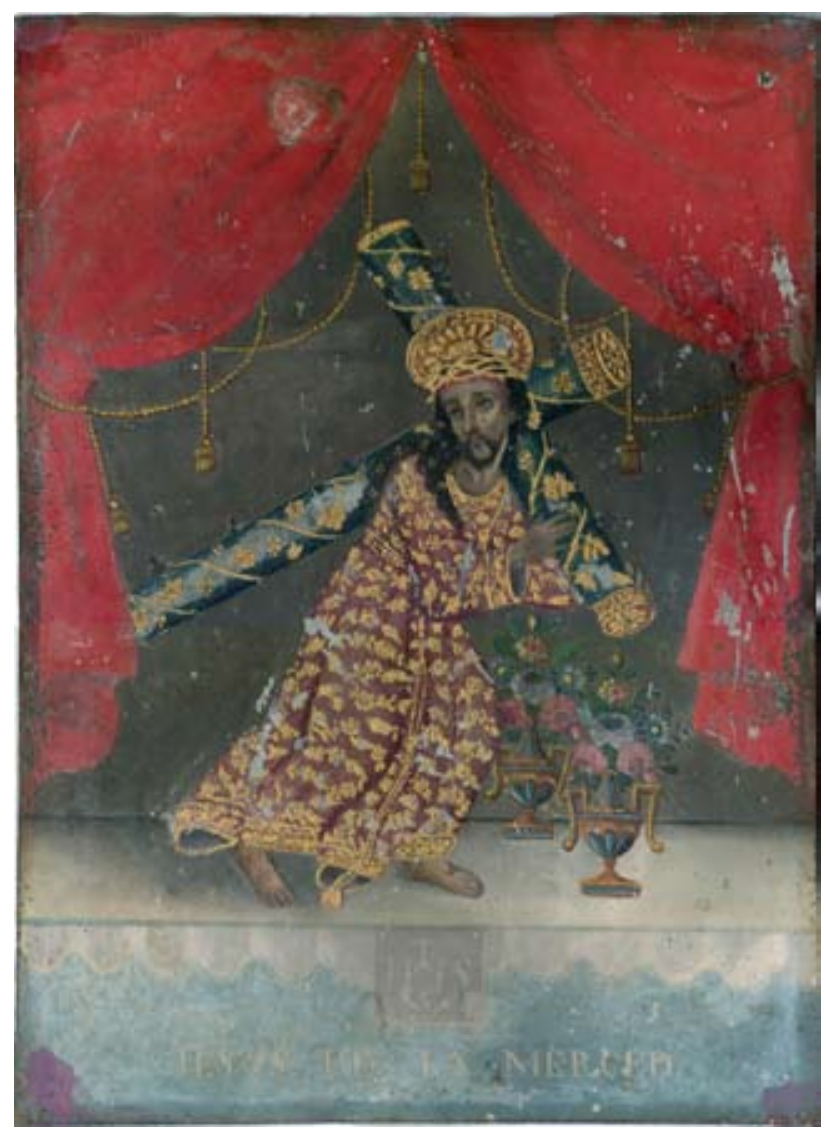

Óleo sobre hojalata, una obra de artista popular en la que se observa la túnica y la cruz enmarcado en su palio formado con el cortinaje rojo 


\section{9 $99^{\circ}$ CONGRESO \\ of $\mathrm{K}$ CENTROAMERICANO \\ UL IIISIOIRIA}

Indexaciones: Repositorio de Revistas UCR, DIALNET, Latindex, REDALYC Directorio y recolector de recursos digitales del Ministerio de Cultura de España, Directory of Open Access Journals.

Diálogos Revista Electrónica de Historia ISSN 1409-469X. Número especial 2008. Dirección web: http://historia.fcs.ucr.ac.cr/dialogos.htm

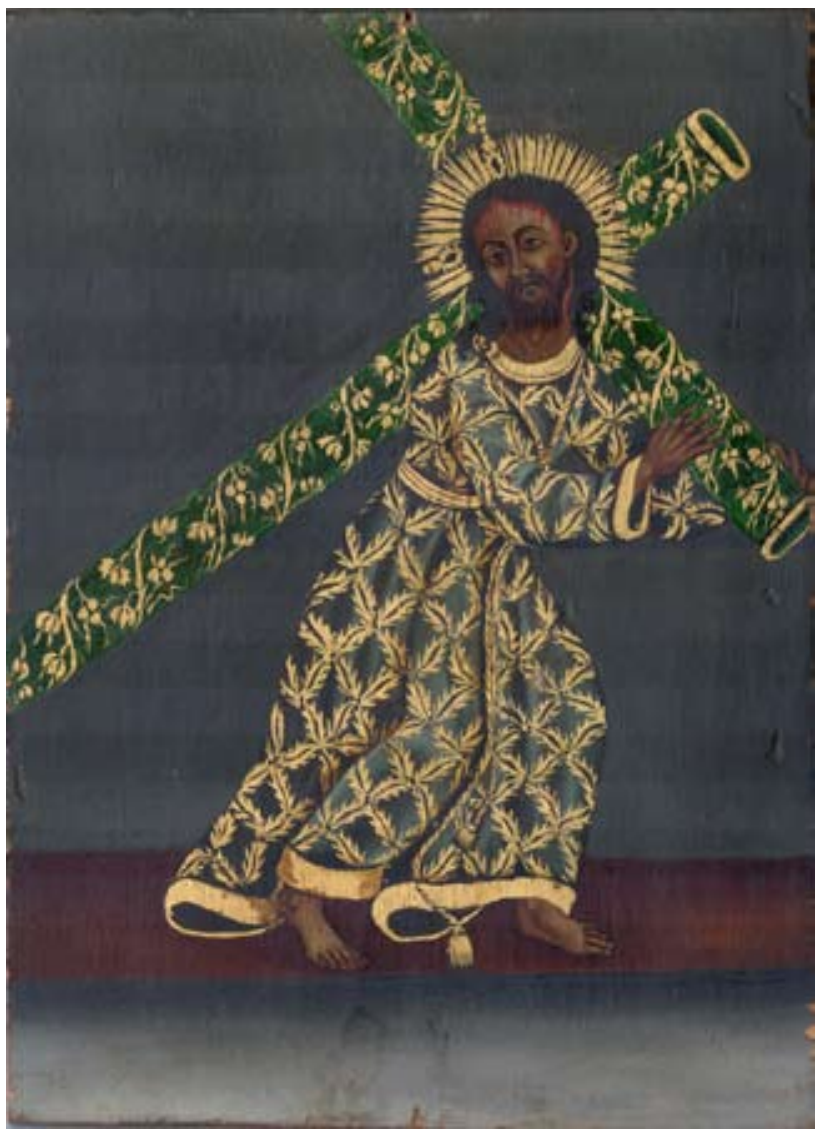

Óleo sobre madera, pintura doméstica de la imagen del Nazareno Mercedario en donde se le muestra con túnica y cruz verde y detalles dorados, véase la colocación de los pies y manos que en este caso no tienen cruces de consagración 


\section{ON9 $9^{\circ}$ CONGRESO \\ of $P$ CENTROAMERICANO \\ d) UL IIIS IOIR}

- ine

Indexaciones: Repositorio de Revistas UCR, DIALNET, Latindex, REDALYC Directorio y recolector de recursos digitales del Ministerio de Cultura de España, Directory of Open Access Journals.

Diálogos Revista Electrónica de Historia ISSN 1409-469X. Número especial 2008. Dirección web: http://historia.fcs.ucr.ac.cr/dialogos.htm

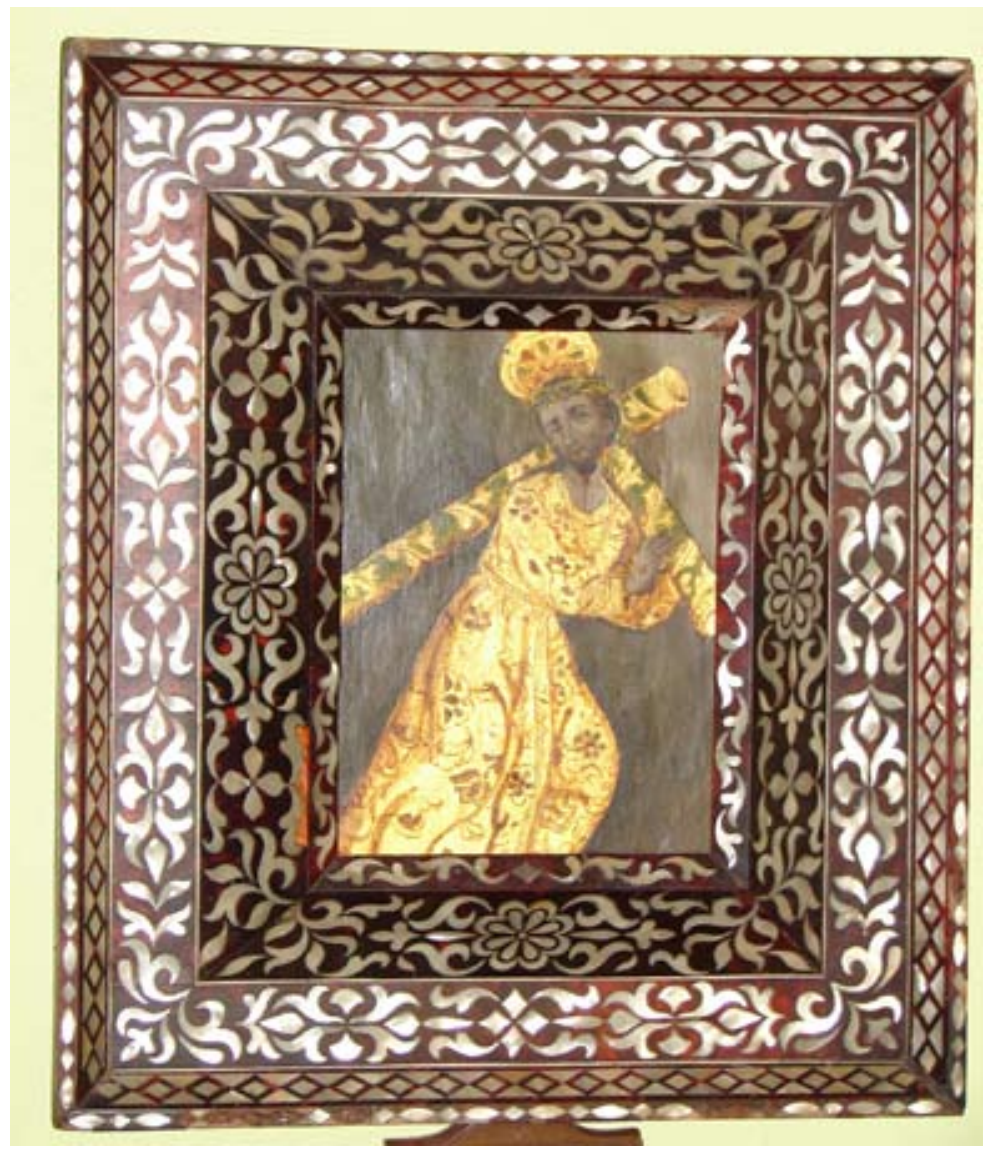

Óleo conservado en Honduras, la obra tiene una fuerte carga de dorados en la túnica y la cruz, mostrando un gusto particular influido posiblemente por la pintura cuzqueña. La pintura posee marco de madera y conchanácar 


\section{OTO $9^{\circ}$ CONGRESO \\ of CENTROAMERICANO \\ of $\mathrm{C}$ UL IIISIOIR}

-

Indexaciones: Repositorio de Revistas UCR, DIALNET, Latindex, REDALYC Directorio y recolector de recursos digitales del Ministerio de Cultura de España, Directory of Open Access Journals.

Diálogos Revista Electrónica de Historia ISSN 1409- 469X. Número especial 2008. Dirección web: http://historia.fcs.ucr.ac.cr/dialogos.htm

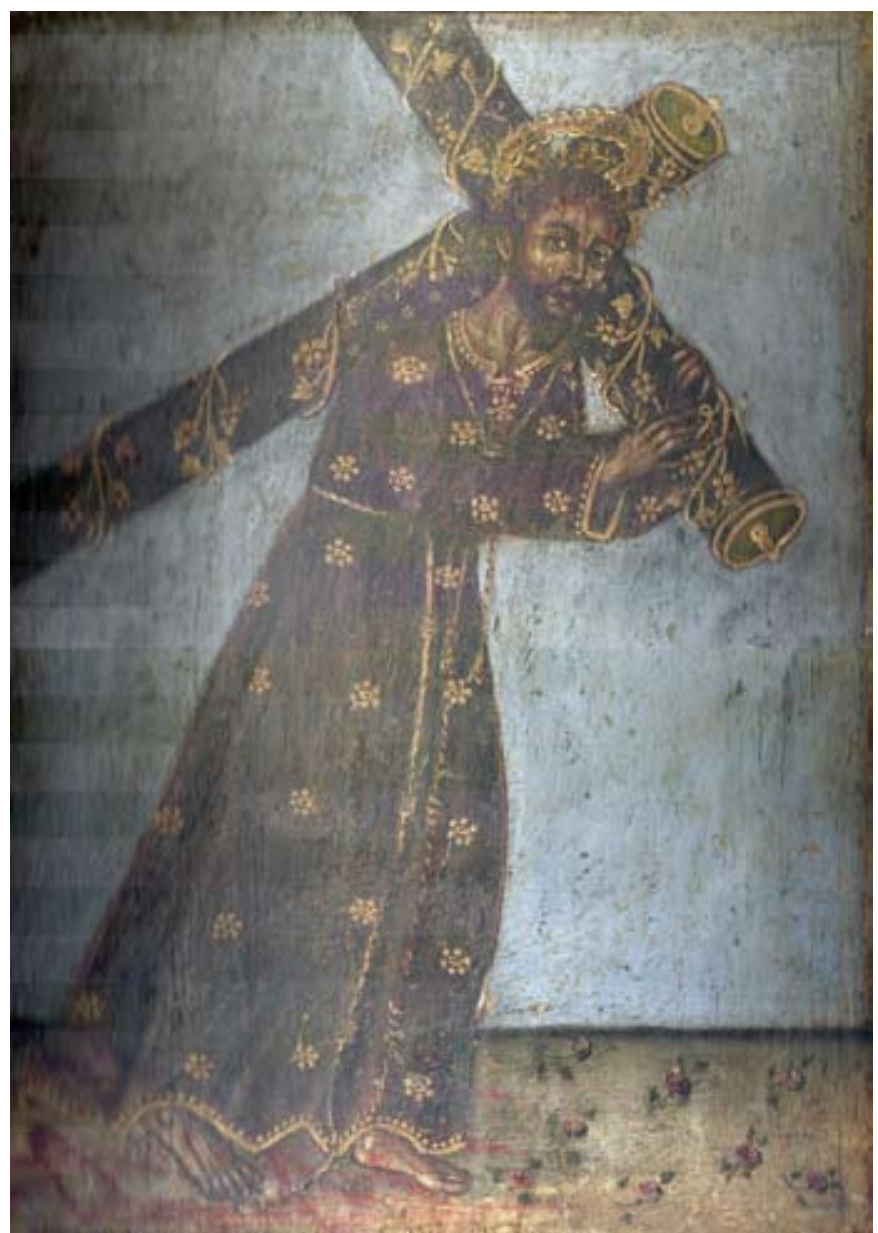

Representación con la túnica morada y detalles dorados resaltados de posibles bordados de flores tipo margaritas, se enlaza a las demás composiciones por la mesa revestida de flores y la cruz con la vid entorchada 


\section{9) $99^{\circ}$ CONGRESO \\ of $\$$ CENTROAMERICANO \\ of $/ \mathrm{S}$ L IIISIOIR IA \\ Don}

Indexaciones: Repositorio de Revistas UCR, DIALNET, Latindex, REDALYC Directorio y recolector de recursos digitales del Ministerio de Cultura de España, Directory of Open Access Journals.

Diálogos Revista Electrónica de Historia ISSN 1409-469X. Número especial 2008. Dirección web: http://historia.fcs.ucr.ac.cr/dialogos.htm

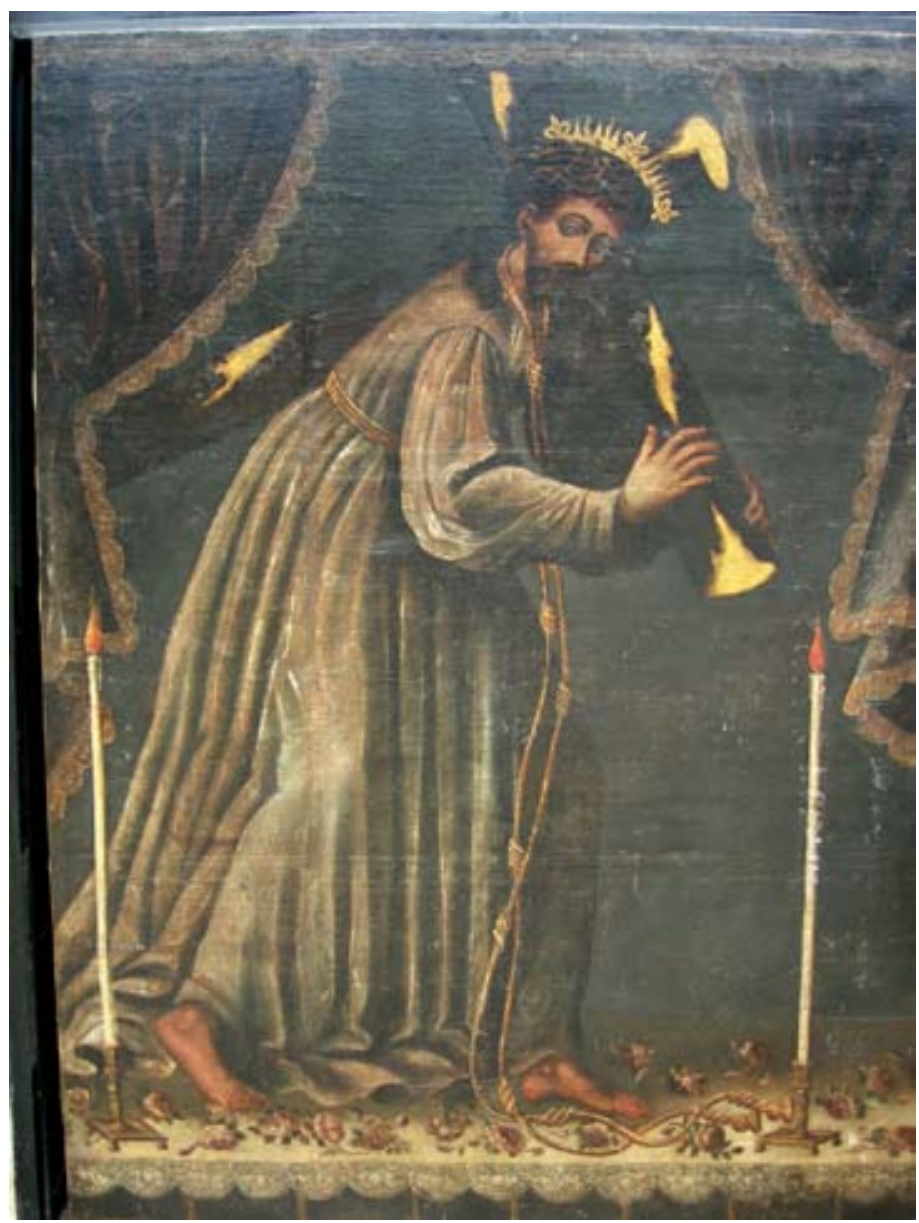

Óleo sobre tela de más de un metro de alto conservador en la Casa de la Cultura de Mixco, Guatemala, rememora posiblemente el paso de esta imagen por dicha población hacia fines del siglo XVIII 